\title{
Turkey and Saudi Arabia as Theo-political Actors in the Balkans: The Case of Bulgaria
}

\author{
ISMAiL NUMAN TELCi* ${ }^{*}$ and AYDZHAN YORDANOVA PENEVA**
}

\begin{abstract}
Turkey and Saudi Arabia have been increasingly utilizing religious services as an instrument in their foreign policies. One of the most recent examples of such active engagement can be seen in Bulgaria. While Turkey has used its shared history and culture with Muslims in Bulgaria, Saudi Arabia has focused more on spreading its national religious identity, Wahhabism Considering these increasing endeavors, this study will focus on how and why the two countries have become active players in the religious sphere in Bulgaria. The study will try to explain the motivations behind such activities and address the impact of this activism on Bulgarian society. The study also aims to reveal motivations, methods and instruments that were utilized in this competition.
\end{abstract}

\section{Introduction}

B ulgaria has been historically a strategic country that served as a center for Balkan politics. This status has given Sofia an attractive position for regional and global actors, which aim to play a role in the Balkans. While the country was ruled by the Ottoman Empire for centuries, the post-World War period changed this picture. Russia became a more influential actor in Bulgarian political and social life, however with its historic and ethnic ties, Turkey continued to play an important role. Following the end of the Cold War, Bulgaria has become the target of other international players. The European Union has played a great role in Bulgaria's rapprochement with the West and this opened up the country to the influence of other actors, including Saudi Arabia. Both Turkey and Saudi Arabia have approached the country through its Muslim minority, who are largely ethnic Turks, actively engaging in the religious sphere amongst the Muslims in Bulgaria.

As a result, the country has witnessed an increase in religious activities of Turkey and Saudi Arabia, the two leading powers in the Muslim world. The main

* Sakarya University, Turkey

**Ankara University, Turkey

Insight Turkey Vol. 21 / No. 2 / 2019, pp. 237-258 
While Turkey approaches Bulgarian Muslims on the basis of their shared cultural and historical similarities as well as similar ethnic identity, Saudi Arabia's main aim is to spread their religious ideology, Wahhabism reason for this is that 15 percent of Bulgaria's population is Muslim. Despite them having different motivations, both Ankara and Riyadh consider Bulgaria as a sphere of influence. Both countries have realized that through closer engagement with this population in Bulgaria, they would become more influential actors in Balkan politics.

The collapse of the Soviet Union and the disintegration of Yugoslavia was a great opportunity for Saudi Arabia and Turkey. Saudi Arabia found the chance to make new allies in the Balkans and Turkey to become close to the previously Ottoman lands. The Iranian Revolution in 1979 was the first time that the Kingdom felt really threatened and it concertedly started exporting its own ideology. A more recent and important event in the Arab world that affected Saudi Arabia was the Arab Spring in 2011. This demonstrated to the Arab countries that their environment is not at all stable and they need to look for new allies in order to maintain their balance. The fact that the rights of the Muslims in Bulgaria have been consistently violated, the long and hard 'cleansing' process, and the dynamics in the region have caused a vacuum not only in the political, economical, and social sphere, but in the religious one too. The country was not able to fill this vacuum, so Saudi Arabia and Turkey 'came to the aid of the Muslims.' Under this guise, they carry out activities to provide religious services to the Muslim community in Bulgaria with both official religious institutions and informal instruments. These services vary from building mosques and religious schools to sending imams, providing scholarships, publishing Islamic books, and delivering financial aid.

Both countries have different motivations for delivering services to Muslims in Bulgaria. While Turkey approaches Bulgarian Muslims on the basis of their shared cultural and historical similarities as well as similar ethnic identity, Saudi Arabia's main aim is to spread their religious ideology, Wahhabism. As a result of these differing agendas, Turkish and Saudi endeavors in Bulgaria, have received differing reactions from the local Muslims. This is mainly because of the fact that Bulgarian Muslims consider Turkish activities as more suitable to their needs, in terms of ideological and practical aspects, while Saudi Arabia's schemes are considered as strategically motivated. To put it differently, it can be observed that while delivering services in Bulgaria, Saudi Arabia's main aim is to expand their Wahhabi ideology to Muslims in this country. This is in line with Saudi Arabia's overall policy of expanding its religious ideology beyond its borders. 
However, the religious understanding among Bulgaria's Muslims is completely different from that of Saudi Arabia. The concept of religion in Saudi Arabia, which has been shaped by the Wahhabi ideology since its foundation, is seen as a radical interpretation of Islam, which is also known as Salafism. On the other hand, Muslims in Bulgaria for many years remained under the administration of the Ottoman Empire and later adopted Islam in the interpretation of their close relationship with Turkey. For this reason, Saudi Arabia's religious projects in Bulgaria are a worry to Muslims living in this country as well as to the Bulgarian government.

Hence, this study focuses on Turkey and Saudi Arabia's religious endeavors in Bulgaria and evaluates how the Muslims in Bulgaria have responded to these two approaches. In doing so, the study initially focuses on the increasing Islamic involvement in Bulgaria by external actors and explores the Turkish and Saudi Arabia activities in detail. Another dimension of the study is to reveal how these religious projects of Turkey and Saudi Arabia may affect the wider socio-political life in Bulgaria.

Considering the limited literature on the subject, the study is of great importance for scholars who wish to make sense of external religious involvement in Bulgaria as well as in the Balkans. The study is especially important for Bulgarian authorities in order to understand the real motivations behind religious activities of Turkey and Saudi Arabia in the country. Another aim of this study is to encourage further studies that focus on religious endeavors of external actors in the Balkan region.

\section{Increasing Islamic Endeavors of External Actors in Bulgaria}

Bulgaria has a very strategic location, between Asia and Europe, so the country is in some way a 'corridor' between both regions. It is a part of the Western sanitary cordon, located in the Balkan geopolitical knot where the interests of global geopolitics have often been confronted. The proximity of Bulgaria to the Caucasian and Middle East geopolitical nodes, the key areas of Bosporus and Dardanelles, the Danube, the Black Sea, and the Adriatic Sea, makes the country a subject of interest. The Balkan geopolitical knot is a hotspot for the interests of Eurasia, Atlantic, and the Islamic world. ${ }^{1}$ Therefore, the Great Powers have always desired to gain more influence in this strategic region.

The country has also its particular strategic value. Bulgaria has the largest percentage of Muslims as a percentage of its total population among the European Union member countries. The Muslim population in the country is more than one million, equivalent to 13 percent of the total population although some estimate this number to be even higher. ${ }^{2}$ Although Muslims in Bulgaria have ex- 


\section{An important aspect of Turkish religious activities in Bulgaria is the fact that the Turkish government provides these services in coordination with the Bulgarian administration}

similation policies and started developing its relations with Turkey. The years of migration to Turkey have created an advantageous situation for Turkey, gaining an important place in Turkey's foreign policy toward Bulgaria. Over the years, the most important factor in Turkish-Bulgarian relations has become the Turkish minority through which Turkey played a role in Bulgarian politics.

There are other Muslim countries that were also interested in the problems of Bulgaria's Muslims. Saudi Arabia has been one of the leading countries in this regard. Following the fall of the Soviet Union, Saudi Arabia increased its involvement in Bulgaria's religious sphere by engaging with Muslims in the country. Increasing Saudi religious activities in Bulgaria have caused Turkey to also increase its involvement, eventually, resulting in a competition between the two countries. This competition was further escalated, as the efforts by the Bulgarian government were not enough to address issues of Muslims in the country.

A further reason for external involvement in Bulgaria was the power vacuum in the post-Soviet era. Bulgaria was very much under the influence of the Soviet Union in terms of political, cultural, and religious life. When the Soviet Union collapsed many countries in the Balkans, including Bulgaria, became open to the interference of more powerful regional and international actors.

The disintegration of Yugoslavia and the collapse of the Yugoslavian economic system were also significant in allowing external actors to become influential players in Bulgaria. ${ }^{7}$ The Balkan states, including Bulgaria were directly affected by those developments both politically and economically. Another impact of such transformations was on the religious groups in Bulgaria, particularly on Muslims. Problems related to religious differences became a source of concern for Bulgaria and it needed help from external actors.

Saudi Arabia and Turkey have actively engaged in religious activities throughout the Muslim world, including countries with large Muslim minorities such as Bulgaria. These endeavors can be divided into three major instruments. These are religious services, education activities, and publishing. Both countries have built or renovated mosques, established religious schools, provided Qur'an courses, published Islamic books, and sent Muslim religious leaders 
The Kingdom's religious

efforts towards Bulgaria's

Muslim community have not been widely welcomed both by the Bulgarian state and the population itself. Turks in Bulgaria adhere to a liberal and moderate understanding of Islam, which sharply contradicts with the Wahhabi ideology which Saudi Arabia aims to spread (imams) in order to help Muslims communities in the Balkan countries to meet their religious needs. This process became more active in the period following 2010, when both countries increased their efforts in these areas.

However, the motivations behind these activities are different. When providing religious services to Muslims in Bulgaria, the main motivation for Turkey is to contribute to ethnic Turks in the country to preserve their cultural and religious identities. This aid is crucial for this community which suffered from the exclusionist policies of the Bulgarian regimes for many years. An important aspect of Turkish religious activities in Bulgaria is the fact that the Turkish government provides these services in coordination with the Bulgarian administration. This allows Turkey to successfully assist the Bulgarian government in providing services to this part of the community.

On the other hand, the main purpose of Saudi Arabia in delivering religious services in Bulgaria is to spread the Wahhabi ideology to this part of the Balkans. By establishing a stronger relationship with the Bulgarian Muslims, Saudi Arabia aims to use the opportunity to strengthen its leadership positions among the Muslims not only in the Middle East but in the Balkans too.

The Balkan region has been considered as an important cultural sphere of influence for Turkey, as the successor of the Ottoman Empire which ruled the region for centuries. Following the withdrawal of the Ottoman Empire, Turkey continued to have strong ties with the Balkan countries and despite its limited foreign policy capacity, Ankara has continued to be influential in Balkan politics. In addition to this, the large Turkish diaspora has played a great role in Turkey's continuing influence in the region. Following the AK Party's rise to power in 2002, Turkey has increased its presence not only in the Middle East but also in the Balkans, a fact that disturbed Saudi Arabia, which can be considered as Turkey's main rival to become the leading actor in the Islamic world. The rising influence of Turkey and its religious role as a 'supporter' of the Muslims in the Balkans is perceived as a threat for Saudi Arabia's leadership position amongst Muslims in the region. Therefore, Saudi Arabia increased its religious, political, and financial efforts in an attempt to balance increasing Turkish influence in the Balkan countries, including Bulgaria. The 
main instrument for Riyadh in this regard was religious activities, which will be detailed in the coming pages of this study.

However, despite Saudi Arabia's endeavors in the region for many years, they have had limited success. The Kingdom's religious efforts towards Bulgaria's Muslim community have not been widely welcomed both by the Bulgarian state and the population itself. The main reason for this is the fact that ethnic Turks in Bulgaria adhere to a liberal and moderate understanding of Islam, which sharply contradicts with the Wahhabi ideology which Saudi Arabia aims to spread.

Furthermore, the main aspect of Turkish religious projects in Bulgaria is that they are in line with the regulations of the Bulgarian government. In addition to this, Ankara and Sofia have been collaborating in such efforts in order to create the best outcomes possible. However, the Saudi endeavors in Bulgaria usually take place without the consent of the Bulgarian government with some of these activities being considered illegal and the government taking action to prevent them from continuing.

It can be claimed that Saudi Arabia and Turkey have different agendas toward Bulgaria with regards to the use of religious activities. While Saudi Arabia has been utilizing religion as a tool in order to gain more influence in the region, Turkey considers religion as an asset to contribute to Bulgarian social and cultural life. These differing approaches create mixed reactions from Bulgarian society. The main reason for this is the different interpretation of the religion of Turkey and Saudi Arabia. Despite the main religion of both countries being Islam, their interpretation of the religion differs. While Saudi Arabia is known to be more radical, Turkey is a secular country with a liberal understanding of Islam, which is similar to that of the Bulgarian Muslim community.

\section{Motivations for Religious Involvement}

It is observed that there is a strong body of literature on the transnational aspect of Islam, particularly those focusing on the religious endeavors of Muslim states in other countries. Remaining within the scope of this study, there are major studies on how the Diyanet (Turkish Presidency of Religious Affairs) operates globally, particularly in European countries. While Bruce emphasizes the great role of the Diyanet as a strategic actor in Turkey's religious activities throughout Europe ${ }^{8}$ Banfi's work details the Diyanet's activities in Switzerland and Italy. ${ }^{9}$ In her book Ceren Lord details the global expansion of the Diyanet and its central role as a foreign policy instrument for Turkey. ${ }^{10}$ In addition to this, the literature on religious efforts of Muslim states in Balkan countries is also worth mentioning. While Merdjanova gives a clear picture of Muslims in the Balkan region, ${ }^{11}$ 
Radical Islam is being

spread among the Roma in some of the ghettos and in

some areas of the Eastern Rhodopes among Bulgarian Muslims (Pomaks), but there is not radical Islam among the Turks in Bulgaria
Korkut details motivations and activities of the Diyanet in the Eurasia region. ${ }^{12}$

Although Turkey and Saudi Arabia have been employing similar instruments in their religious activities in Bulgaria, their motivations and target groups differ. While Turkey is engaged mostly with the ethnic Turks in Bulgaria, Saudi Arabia is focusing on the economically less developed areas of the country. The main reason for this is that Turkey has

historical ties with the ethnic Turks in Bulgaria and feels the responsibility to show solidarity with this minority. As ethnic Turks of Bulgaria share the same belief system of Turkey, the Hanafi school of Sunni Islam, the Turkish state assumes a natural dynamic to help this society in Bulgaria. Another difference between the Turkish and Saudi approach is the differing interpretation of Islam of both countries. Although both are Sunni, Saudi Arabia's radical and conservative Islam is confronting Turkey's 'soft and secularized' Islam. Despite the fact that the fundamental beliefs are the same, due to the divergences in their practices, to the two states demonstrate their differences in their identities and their political aims. Saudi Arabia uses some components of its culture and religion and calls itself, "the custodian of the two Holy Mosques." It actually represents itself as the defender of certain values in order to determine its political legitimacy. It funds some Islamic organizations and tries to influence people's understanding of Islam and make them accept the Saudi religious ideology in order to maintain its role as a leader in the Islamic world.

Another dynamic is the geostrategic rivalry between Turkey and Saudi Arabia. Both countries have been in competition for regional leadership in the economic, political, and cultural sphere. This has reflected in their foreign policies, particularly in regions where both of them have some or extensive influence. ${ }^{13}$

The poorer Muslim regions are the most successful means by which Saudi Arabia can spread its interpretation of Islam. Saudi Arabia has done this in the Rhodopes region where a large number of Pomaks, ethnic Bulgarian Muslims, live. ${ }^{14}$ In comparison with the Turks in Bulgaria, the Pomaks are poorer and they feel isolated from the rest of the population. So, the environment in this region is appropriate for the radicalization of Muslims. Saudi Arabia has built a number of mosques and the religious leader of Rhodopes has studied in the Kingdom.

According to the statement made by the Minister of Defense Krasimir Karakachanov, radical Islam is being spread among the Roma in some of the ghettos 
and in some areas of the Eastern Rhodopes among Bulgarian Muslims (Pomaks), but there is not radical Islam among the Turks in Bulgaria. He has also stated that the people in poorer areas can be radicalized more easily than other parts of the country. ${ }^{15}$

\section{Turkey's Religious Activities in Bulgaria}

The Balkans region is a place which is accepted to be very close not only geographically but also historically and culturally to Turkey. Ethnic Turks in Bulgaria are Muslim and they feel a sense of belonging to Turkey as their historical homeland. The experience of 1989 further shaped and strengthened the ethnic identity of the Turks in Bulgaria and the transition to democracy played a very important role. ${ }^{16}$ While Saudi Arabia is a foreigner in the region, Turkey feels emotionally tied to the geography and its people there. Turkey is trying to spread its interpretation of Islam in Bulgaria, where the Muslims have been 'oppressed,' their rights have been violated, and they did not have the opportunity to continue their religious practices. As a neighboring country, Bulgaria has a very important place in Turkish foreign policy, which has recently put more focus on the Turks and Muslims in Bulgaria. This trend started with the rise of the AK Party to power in 2002. Since then, one of the most important characteristics of Turkey's foreign policy has been the opening of the country to wider geographies in terms of politics, religion, culture, and economy. The orientation of Turkey to the Balkans was actually a sign of the beginning of the new Turkish foreign policy.

The leading Turkish organization that provides religious services in Bulgaria is the Turkish Presidency of Religious Affairs, the Diyanet. The organization signed an agreement with the Bulgarian government and received a special status in sponsoring Muslims in the country. ${ }^{17}$ The main religious activity of Turkey in Bulgaria is to establish Islamic schools that are known as Ilahiyat Lisesi (Theology High Schools). In recent years, such schools were founded in the cities of Rusu and Shumen, while another was built with the support of Turkish Religious Foundation (Türkiye Diyanet Vakf, TDV) and Turkish Cooperation and Coordination Agency (Türk İşbirliği ve Koordinasyon Ajansı, TİKA) in the city of Momchilgrad in 2012. ${ }^{18}$ These high schools provide Islamic education in line with a curriculum that is prepared in coordination with Turkish educational institutions. While Turkey provides logistical support for these schools, it also organizes social activities in order to enhance the cooperation between Turkish and Bulgarian educational professionals. ${ }^{19}$

Turkey provided significant support for the establishment of a Higher Islamic Institute in Sofia (Yüksek Islam Enstitüsü). Since its establishment in 1990, the Institute provides higher education in Islamic Studies with the TDV covering 


\section{Turkish religious activities in Bulgaria can also be observed in religious services with significant financial aid provided to build mosques throughout the country}

the costs of education and other activities related to the Institute. ${ }^{20}$ The TDV provides maintenance support and educational materials to all the Islamic schools that operate in Bulgaria and support to the teachers and educational professionals of these schools. Despite receiving financial support from Turkey, they are under the control of Bulgaria's Chief Mufti's Office. As they have a private status, the Bulgarian government has little interference in their activities, however, these schools are registered under the National Education Act. ${ }^{21}$ In addition to official education activities, Turkey sponsors imams to make temporary visits to Bulgaria to teach Islamic courses in cities and villages. Such activities particularly take place in the summer school vacation when students attend Qur'anic courses in mosques. ${ }^{22}$

Turkish religious activities in Bulgaria can also be observed in religious services with significant financial aid provided to build mosques throughout the country. ${ }^{23}$ Turkey sends financial support for mosques and other Islamic institutions in order to cover their water, electricity, and gas bills as well as the salaries of religious leaders and teachers. Additionally, various needs of the Bulgarian Chief Mufti and its regional branches, such as office supplies, repair materials, carpets, electronic devices, and published materials were provided by TDV. Turkey organizes Islamic events such as circumcision (Sünnet) and Aid al-Adha (Kurban) for the Bulgarian Muslims in order to ensure that they can fulfil their Islamic obligations. ${ }^{24}$ Providing renovation services for historic religious sites in Bulgaria is another important area of involvement and Ankara has sent nearly 3 million BGN for the restoration of Tombul Mosque in Shumen and Banya Bashi Mosque in Sofia. ${ }^{25}$

Turkey also supports Bulgarian Muslims by sending religious clerics in order to meet their needs throughout the year. In particular, many imams come to Bulgaria during the holy month of Ramadan and provide a month-long service for Muslims in the country. During Ramadan, Turkey provides food aid and supports an association, which has been founded by Bulgarian Turkish students. ${ }^{26}$ In addition, TDV provides the religious robes used in mosques and Mufti's offices.

Another area of Turkish support is publishing services for the Muslim community in Bulgaria. The main activity in this regard is to publish a Bulgarian translation of the Qur'an and other religious books, providing essential religious materials for the Muslim community in Bulgaria. 

In addition to its vast reserves of oil, Saudi Arabia has been utilizing Islam as a foreign policy tool to exert its influence in the Islamic world as well as on Muslim minorities globally cides with the dynamics of the Bulgarian social structure.

The third reason is that the Turkish activities would encourage Bulgarian Muslim youth to distance themselves from radical ideologies and organizations such as ISIS. This is crucial for the Bulgarian government to prevent radical Islam from gaining ground in Bulgaria. ${ }^{31}$ The region has witnessed the rise of radicalization, which emerged as a result of increased activities of Salafi and Wahhabi preachers. Some of these imams have been employed in mosques and religious institutions, which were established with the financial support of Saudi Arabia. Therefore, Turkish efforts work to counter such initiatives that would otherwise have a destructive effect on Bulgarian social fabric.

However, despite Bulgaria's positive attitude toward Turkey's religious activities in the country, there are also various conflicting issues. While Bulgaria has welcomed Turkey's religious projects in the country, it also urged Ankara to refrain from any intervention into Bulgaria's domestic politics. Ankara has been very cautious in this regard. However, due to complaints by the Bulgarian authorities, Sofia has at times expelled Turkey's religious figures from the country. In January 2009, Bulgaria Coordinator of Türkiye Diyanet Vakfi, Adem Yerinde, was expelled from the country, ${ }^{32}$ while in February 2016, the religious attaché of Turkey in Bulgaria, Uğur Emiroğlu, was announced persona non grata. Reports claimed that the reason for the decision was not related with religious disputes but rather with claims of interference into domestic affairs. ${ }^{33}$ These crises, however, did not escalate further, as both governments did not want to damage bilateral relations. In addition to welcoming Turkey's religious services in the country, Bulgaria considers Turkey a key ally in economic cooperation as well as fighting against illegal migration.

A clear indicator of this mutual understanding is the effort by Turkey to renovate the Church of St. Stefan in İstanbul, a building which has a great historical importance for Bulgaria. While the opening ceremony in January 2018 hosted religious and political leaders from both countries including Turkish President Recep Tayyip Erdoğan, Bulgarian Prime Minister Boyko Borissov, Patriarch Neofit of the Bulgarian Orthodox Church, and the Ecumenical Patriarch of Constantinople, there were strong messages of cooperation. Bulgarian Prime Minister Boyko Borissov said that, "This is a great day, and a very good investment in the future. Let us show the whole of Europe and the Christian world that we can improve relations with our biggest neighbor [Turkey]. Small as we are, we will try to contribute to this mutual understanding." ${ }^{34}$ 
Another important step in this regard was Bulgaria's decision to allow Turkey to renovate an Ottoman-era mosque in the Bulgarian town of Razgrad. Presently closed for prayers, Ibrahim Pasha Mosque's restoration was discussed during a meeting led by Prime Minister Boyko Borisov. The meeting concluded that the mosque, which is defined as the biggest Ottoman architectural work in the Balkans, would be restored by Turkey. It was also announced that Razgrad's Turkish-origin governor Günay Hüsmen has been appointed to oversee the reconstruction process. ${ }^{35}$

\section{Saudi Arabia's Religious Activities in Bulgaria}

Historically, one of the main instruments of Saudi Arabian foreign policy is Islam. In addition to its vast reserves of oil, ${ }^{36}$ Saudi Arabia has been utilizing Islam as a foreign policy tool to exert its influence in the Islamic world as well as on Muslim minorities globally. While the revenue from oil has provided Saudi leadership with the financial capabilities to become a regional power base, instrumentalization of religion has allowed the Kingdom to gain a leadership position amongst the Muslim countries, particularly in the Middle East and North Africa. Saudi Arabian leadership has focused more on instrumentalizing Islam in its foreign policies, especially in the past three decades. This is mainly because of the fact that the holiest places of Islam, Mecca and Medina, are located in Saudi Arabia and for this reason the country has tried to frame itself as the natural leader of the Muslim world. Moreover, Saudi leaderships have labeled themselves as Khadim al-Haramayn al-Sharifayn (custodian of the two Holy Cities) in order to emphasize their leading position for Muslims globally. As a result, the Kingdom presents itself as the only actor that has the responsibility of introducing the true and genuine image of Islam. ${ }^{37}$ Therefore, it can be argued that successive Saudi governments have consistently integrated religion into their foreign policy making processes and Islam has become an instrument in the country's foreign policy.

While religion is not the only feature that determines the nature of Saudi Arabia's foreign policy, it has been a central element of the Saudi foreign policy for decades, even during the Cold War era. ${ }^{38}$ In order to support the United States against the Soviet Union, Saudi Arabia tried to engage with Muslim populations in the Soviet Union as well as the Balkan countries. These efforts were even admitted by the current Saudi Crown Prince, Mohammad bin Salman who said "investments in mosques and madrassas overseas were rooted in the Cold War, when allies asked Saudi Arabia to use its resources to prevent inroads in Muslim countries by the Soviet Union." ${ }^{39}$ Bin Salman also argued that "Wahhabism was used as a tool against the Soviets during the Cold War era, and the Saudi-funded expansion of the sect was done on the demand of the United States." 40 In fact, one of the countries with a Muslim community in 
which Saudi Arabia has invested during the 1980s and 1990s was Bulgaria. The country has continued to play a central role in Saudi Arabia's utilization of Islam as a foreign policy instrument in the post-Cold War era.

In recent years Saudi Arabia has been increasingly trying to export its religious ideology, Wahhabism, in order to gain popular support in Muslim countries as well as within Muslim minorities in various regions. ${ }^{41}$ As stated above, religion is considered as one of the most powerful tools for Saudi Arabia in reaching out to Muslim societies throughout the world. Adopting and spreading Islam is one of the elements of the Saudi identity.

The strong relationship between the royal family and the religious clerics has played a very important role in the shaping of the conservative religious views of Saudi Arabia. ${ }^{42}$ In addition, the fact that the holiest places for Islam (Mecca and Medina) are part of Saudi Arabian lands has strengthened the relationship between the state and the religious leaders which has to a large extent influenced Saudi Arabian foreign policy.

Saudi Arabia has been following an active foreign policy during the past decade. This process has accelerated since the start of the Arab uprisings in 2010 in Tunisia. The Riyadh Administration realized that it must reach out to traditional destinations in terms of its foreign policy agenda and one of the dynamics in this regard is the role of religion in Saudi foreign policy. Traditionally Saudi Arabia has been trying to export its religious ideology, Wahhabism. This is observed in Saudi Arabia's relations with Muslim countries around the world, particularly in the Sunni world, where it aims to export its religious ideology in order that these communities have a positive approach to the Saudi state. Bulgaria is one of the examples where Saudi Arabia's religious endeavors can be observed.

While Saudi Arabia provides scholarships for Bulgarian students who want to study in the Islamic universities in the Kingdom, it also helps the Muslim community of Bulgaria financially. This includes building mosques and Islamic schools, providing religious material, and sending Saudi clerics to spread Wahhabi ideology or funding local imams with similar ideologies.

Saudi Arabia started its religious activities in Bulgaria in 1989.43 Various Wahhabi clerics and religious figures came to the country in 1992 in order to teach their version of Islam. These Saudi-funded Islamic NGOs registered as foundations and started building mosques and religious institutions in different villages throughout the country. ${ }^{44}$ The main objective was to spread the Wahhabi ideology, which is in contradiction to the form of Islam that Bulgarian Muslims traditionally adhere to. Despite this agenda, Bulgarian authorities welcomed Saudi funding as the country was in need of religious services to its Muslim 
community. However, after the Bulgarian government realized that some of these organizations were supporting extremism and causing the radicalization of Bulgarian Muslims, Sofia decided to shut them down. Dar al-Irshad and Al Waqf al-Islamiyya were closed for such reasons. However, Saudi Arabia has continued its activities with new officially registered NGOs such as Taiba, Al Wakf al-Islami, ${ }^{45}$ and Nedua. ${ }^{46}$
Despite these concerns of the Bulgarian administration about the spread of Wahhabi ideology as well as Turkey's influence in the country, Sofia has largely welcomed the financial support and the activities of both countries

Taiba focuses on construction and maintenance with the organization funding the building of new mosques and religious schools. Even though in 1997 the organization's leader Abdurrahman Takan was expelled from Bulgaria for conducting illegal preaching against the state, Taiba continues to send students to study Quran, Hadeeth, and Arabic in the Middle East. ${ }^{47}$ Nedua provides funding to those wishing to go on pilgrimage to Mecca. The Hajj and Umrah pilgrimages to Mecca and Medina also contribute significantly to Saudi Arabian religious 'soft power.'

Despite many of the Saudi Arabia funded Islamic NGOs being registered by Bulgarian authorities, there are also unregistered organizations that are operating in the country. Igasse ${ }^{48}$ is known to be one of the unregistered Saudi-funded organizations with an active agenda in Bulgaria. ${ }^{49}$ It is claimed that some of the registered and unregistered religious organizations funded by Saudi Arabia have opened schools or published books illegally. ${ }^{50}$ There are also claims that some of these organizations have been promoting radical ideologies.

\section{The Effect of Foreign Religious Activities on Bulgaria}

It can be argued that Bulgaria's Muslim minority has a more liberal understanding of Islam than Muslims in Turkey ${ }^{51}$ However, as Bulgarian Muslims also follow the Hanafi branch of Sunni belief, their practices are closer to those of Turkey than Saudi Arabia. ${ }^{52}$ Doubtless, the period under Communism and the thirty-five-year reign of Todor Jivkov has had a serious impact on the religiousness of the Muslims in Bulgaria. However, since 1989, when a new era began in Bulgarian politics, Sofia aimed to improve its relations with its centuries-old neighbor Turkey. This decision was taken because Bulgaria needed to have Turkey's support for NATO membership, and the greater size and strength of Turkey's military forces meant that good relations with Turkey were crucial for their security. Moreover, Turkey's economic stability was a good opportunity for the country's economy. ${ }^{53}$ 


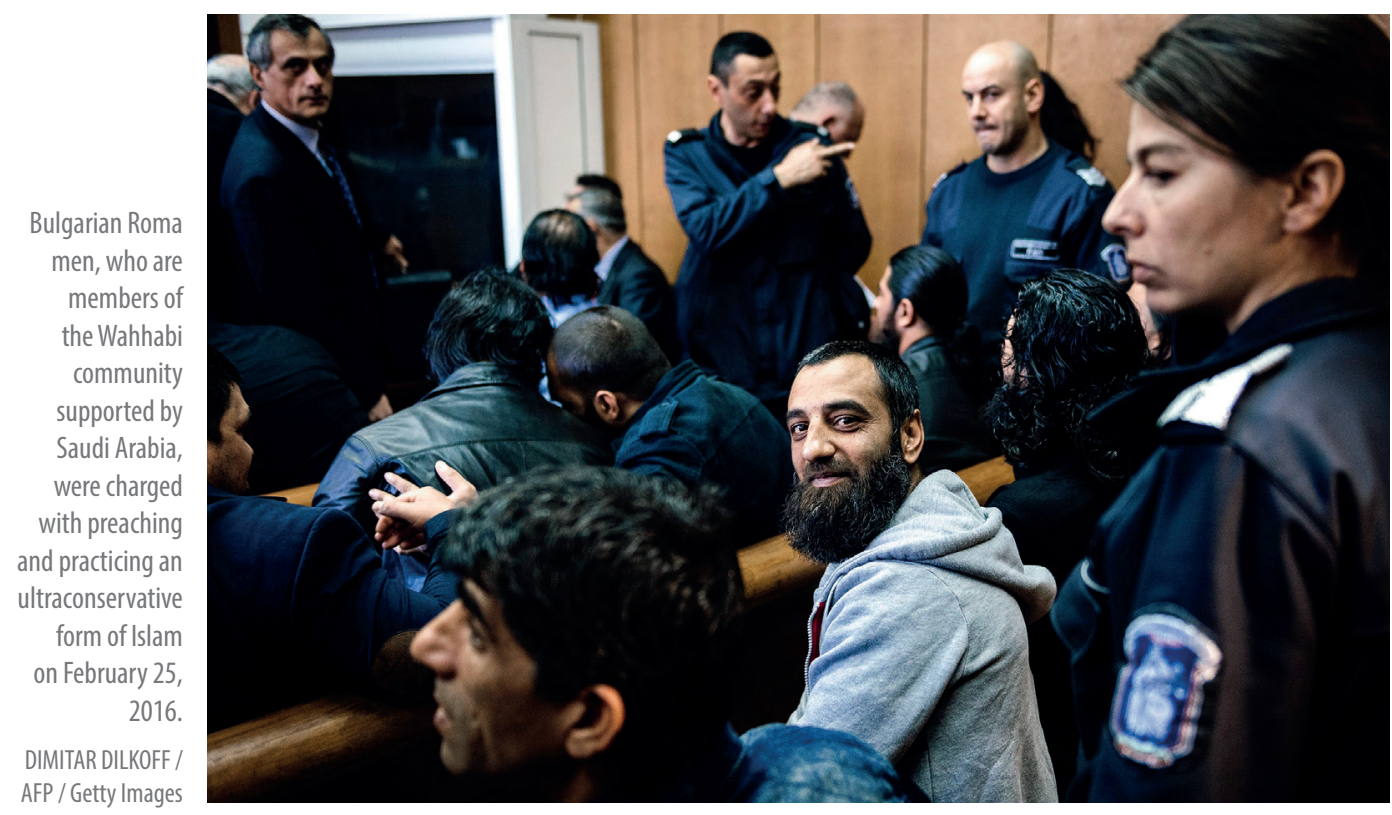

With the increasing influence and power of Turkey, Ankara became more interested in becoming involved in the cultural and social life in Bulgaria. This was mainly because of the shared values and historical ties between Turkey and the Muslim minority in Bulgaria. The Turkish government soon became an active player in Bulgaria's social life and Turkey-based NGOs have become more active in the country.

On the other hand, Saudi Arabia's religious activities in Bulgaria were considered as efforts to spread Salafi Wahhabism. Saudi Arabia was further accused of exporting radicalization to this part of Europe, therefore, Saudi religious activities were cautiously welcomed and they did not have a chance to find their way amongst Bulgaria's Muslims. In addition to this, when Bulgarian authorities realized that the primary aim of Saudi religious endeavors was to spread the Wahhabi ideology in the country, they become more suspicious of these projects and took decisions to prevent their activities.

Another reason for the fear for Saudi Arabia's involvement in religious affairs in Bulgaria is the fact that most imams and clerics who have completed their education in Saudi Arabia embrace the core values of Wahhabism. Bulgarian authorities are concerned that these religious figures would help to spread the Wahhabi ideology. ${ }^{54}$ The spread of Wahhabi ideology is generally regarded as radical Salafism, from which terror organizations such as ISIS or al-Qaeda are said to derive their ideology. The concern is that increasing interaction of Saudi religious practitioners with Bulgarian nationals would cause the rise and 
spread of radicalization amongst the Muslims in the country. This would eventually introduce into Bulgaria conflicts and terrorist ideology that are normally based in the Middle East. Therefore in a number of cases the government of Bulgaria has had to take action against imams who were considered to be trying to spread Wahhabism.

The Saudi endeavors in Bulgaria have also contributed to the increased momentum in the rise of right wing political ideologies in the Bulgarian mainstream media trigger hostility toward Muslims throughout the county. Steps taken by Saudi Arabia in terms of religion are seen as radicalization efforts that would damage the social fabric of the country.

Despite these concerns of the Bulgarian administration about the spread of Wahhabi ideology as well as Turkey's influence in the country, Sofia has largely welcomed the financial support and the activities of both countries. An important reason for this is the fact that Bulgaria does not have the financial and practical capabilities to respond to the needs of its Muslim population. However, the country continues to feel suspicious about the real motivations of the Saudi Arabian involvement in the country's religious sphere.

One of the problematic issues of Saudi religious activities in Bulgaria is the fact that the Saudi understanding of Islam is significantly different from the interpretation of Islam by Bulgarian Muslims. Because of the centuries long Ottoman legacy the Bulgarian understanding of Islam is rather liberal and strongly embedded with Sufi traditions, similar to that of modern day Turkey. ${ }^{55}$ This is also a reason why Bulgarian Muslims feel much closer to their fellow Muslims in Turkey. As a result, while Saudi religious activities are welcomed on the surface, they are not able to make a serious impact on the majority of the Muslims in Bulgaria.

However, Pomaks, who are Muslims and at the same time ethnically different from Turks, are a concern for the Bulgarian state. As Pomaks are somewhat detached from Turkish origin Muslims in the country, they may be exposed to ideological indoctrination by Saudi scholars and imams. Financially in a disadvantaged position, Pomaks are one of the most important target groups for Saudi Arabian religious activities. If such tendencies grow among Pomaks, 
While Turkey has endeavored to help Bulgarian Muslims because of their ethnic and religious similarities, Saudi Arabia has taken advantage of their low economic and living standards they will differentiate themselves from other Muslim communities in Bulgaria which may create some sort of sectarian tension. Therefore, the Pomaks' vulnerability to radicalization is another source of concern for the Bulgarian Administration in this largely conflict-free country. Another concern for the Bulgarian government is that it may fall under some kind of political influence of either Saudi Arabia or Turkey, the two leading countries that have different foreign policy objectives in the Middle East and elsewhere. Both countries have been in stark competition for the leadership position in the Muslim world, particularly since 2011, the post-Arab revolutions era. This competition between these two states could compel Bulgaria to have to take sides in foreign policy matters.

\section{Conclusion}

The disintegration of Yugoslavia has seriously shaken the balance in the Balkans. The instability has reached dangerous levels in terms of international peace. The consequences have caused a vacuum in the political, social, economic, and religious arena. This vacuum has been quickly filled by a number of regional and international actors, including Turkey and Saudi Arabia. Both countries have tried to become more influential players in the region in order to expand their geopolitical reach. While Saudi Arabia has utilized its economic wealth and central role in Islam, Turkey presented itself as the historical ally of Muslims in the Balkans. This process has further accelerated since the new millennium when Turkey became an active foreign policy player in the region and Saudi Arabia started to follow an aggressive foreign policy both in the Middle East and in the Balkans.

This process has brought about a competition between the two countries. While Turkey and Balkan countries share a common history and cultural similarities, Saudi Arabia has little commonality with the region, apart from religion. This did not prevent Saudi Arabia from intervening in the Balkan regions in order to spread its religious ideology. This, however, was not welcomed by the Muslim societies of the region. On the other hand, because of its cultural and historical ties, Muslims in the Balkans welcomed Turkish religious endeavors. This study investigated how this situation has worked in the case of Bulgaria.

Both Riyadh and Ankara focus on facilitating the expansion of the services and assistance provided to Muslim communities in the Balkans. Generally, 
these policies include scholarships, organization of educational programs for religious personnel, facilitating the Islamic pilgrimage, and publishing of books including translating the Qur'an into local languages. Both countries perceive the importance of Islam in the past and the present. Therefore, they are competing to become the religious leaders of the Muslim world. Although both of them are Sunni, they are trying to spread the form of Islam that they accept as legitimate.

While Turkey has endeavored to help Bulgarian Muslims because of their ethnic and religious similarities, Saudi Arabia has taken advantage of their low economic and living standards. The Riyadh Administration has used this situation in order to increase its influence in Bulgarian politics. As Turkey encouraged a moderate version of Islam to Bulgarian Muslims, Saudi Arabia's main aim was to spread the Wahhabi ideology among the Muslim society in the country. Despite these obvious differences in their approach to the region, Turkey and Saudi Arabia have not publicly seemed to compete with each other. However, after a detailed observation on why and how these countries intervene in the Bulgarian social fabric, it can be said that there is an obvious competition between Riyadh and Ankara to become more influential among the Muslims in Bulgaria as well as in the Balkan region. However, as Saudi Arabia's understanding of Islam is considered too radical for Muslims in Bulgaria, they tend to be more welcoming to the Turkish approach, which is traditionally more tolerant and moderate.

\section{Endnotes}

1. Maya Stoyanova, "Bulgaria's Role in the Security of the European Union," Presidency of Bulgaria, retrieved May 22, 2018, from https://www.president.bg/docs/1355396994.pdf.

2. "Muslims and Christians Celebrate Together in Bulgarian Town," Balkan Insight, (July 7, 2016), retrieved January 8, 2019, from http://www.balkaninsight.com/en/article/muslims-and-christians-celebrate-together-in-bulgarian-town-07-07-2016.

3. "Bulgaria: The Sufferings of One Million Muslims," Islam Web, (September 25, 2006), retrieved January 8, 2019, from http://www.islamweb.net/en/article/136011/bulgaria-the-sufferings-of-one-million-muslims.

4. Halil Akman, Paylaşılamayan Balkanlar, (İstanbul: IQ Kültür Sanat Yayıncılık, 2006), p. 260.

5. Pomaks are considered as Bulgarian Muslims.

6. Akman, Paylaşılamayan Balkanlar, p. 260.

7. Bilgehan A. Gökdağ and Osman Karatay, Balkanlar El Kitabı, 2. Cilt: Çağdaş Balkanlar, (Ankara: Akçağ Yayınları, 2013), p. 33.

8. Benjamin Bruce, Governing Islam Abroad: Turkish and Moroccan Muslims in Western Europe, (Cham: Palgrave, 2019), pp. 33-40.

9. Elisa Banfi, Welfare Activities by New Religious Actors: Islamic Organisations in Italy and Switzerland, (Cham: Palgrave, 2018).

10. Ceren Lord, Religious Politics in Turkey: From the Birth of the Republic to the AKP, (Cambridge: Cambridge University Press, 2018). 
11. Ina Merdjanova, Rediscovering the Umma: Muslims in the Balkans between Nationalism and Transnationalism, (New York: Oxford University Press, 2013).

12. Şenol Korkut, "The Diyanet of Turkey and Its Activities in Eurasia after Cold War," Acta Slavica laponica, Vol. 28, pp. 117-139.

13. Evangelos Venetis, "The Struggle between Turkey and Saudi Arabia for the Leadership of Sunni Islam," Hellenic Foundation for European and Foreign Policy, Working Paper No. 39 (February 2014), retrieved January 15, 2019, from https://www.eliamep.gr/wp-content/uploads/2014/02/WORKINGPAPER-_Venetis-Ev.pdf.

14. Evgeniya Ivanova, Identity and Identities of Pomaks in Bulgaria [Иванова, Евгения, Идентичност и идентичности на помаците в България), Inforno, retrieved May 22, 2018, from http://journal-informo. eu/content/014/003.pdf.

15. Diyana Panayotova, "Karakachanov Clarified the Places that Radical Islam Is Being Spread [Панайотова, Диляна. Каракачанов разкри къде у нас има радикален ислям)," News.bg, (November 9, 2017), retrieved May 2, 2018, from https://news.bg/politics/karakachanov-razkri-kade-u-nas-imaradikalen-islyam.html.

16. Hugh Poulton and Suha Taji-Farouki, Muslim Identity and the Balkan State, (London: Hurst \& Company, 1997), p. 71.

17. Merdjanova, Rediscovering the Umma, p. 21.

18. "Bulgaristan'a Illahiyat Lisesi Açıldı," Yeni Şafak, (July 7, 2012), retrieved January 10, 2019, from https:// www.yenisafak.com/dunya/bulgaristana-ilahiyat-lisesi-acildi-393252.

19. "Bulgaristan'da Din Öğretimi Veren Ortaöğretim Kurumları Yönetici, Öğretmen ve Çalışanlarına İstanbul'da Hizmet İçi Eğitim Programı Düzenlendi," T.C. Milli Eğitim Bakanlığı, (May 15, 2018), retrieved January 10, 2019, from http://dogm.meb.gov.tr/www/bulgaristan8217da-din-ogretimi-veren-ortaogretim-kurumlari-yonetici-ogretmen-ve-calisanlarina-istanbul8217da-hizmetici-egitim-programi-duzenlendi/icerik/662.

20. "Bulgaristan Müslümanlarının YÖK'ten Beklentisi," Yeni Akit, (September 7, 2016), retrieved January 10, 2019, from https://www.yeniakit.com.tr/yazarlar/serdar-demirel/bulgaristan-muslumanlarinin-yokten-beklentisi-16959.html.

21. Турция издържа три мюсюлмански училища у нас, Blitz, (December 5, 2014), retrieved from https://www.blitz.bg/obshtestvo/turtsiya-izdrzha-tri-myusyulmanski-uchilishcha-u-nas_news306452. html.

22. "Bulgaristan Müslümanları," Kırcaali Haber, (February 11, 2010), retrieved January 12, 2019, from https://www.kircaalihaber.com/?pid=3\&id_news=5582.

23. "Turkey Pours BGN 12 M to Build Largest Mosque in Bulgaria," Sofia News Agency, (April 4, 2012), retrieved January 12, 2019, from https://www.novinite.com/articles/138209/Turkey+Pours+BGN+12+ M+to+Build+Largest+Mosque+in+Bulgaria.

24. "Bağcılardan, Bulgaristan'da Toplu Sünnet Töreni," Hürriyet, (July 26, 2017), retrieved January 12, 2019, from http://www.hurriyet.com.tr/bagcilardan-bulgaristanda-toplu-sunnet-toreni-40531785; “Diyanet Vakfı Aynı Anda 100 Çocuğu Sünnet Ettirdi," Türkiye Diyanet Vakfı, (July 21, 2018), retrieved January 12, 2019, from https://www.diyanethaber.com.tr/tdv/diyanet-vakfi-ayni-anda-100-cocugu-sunnet-ettirdi-h782.html.

25. "Bulgaristan'daki Osmanlı Camileri Büyükşehir ile Hayat Buldu," Bursa Büyükşehir Belediyesi, (June 27, 2013), retrieved January 12, 2019, from https://www.bursa.bel.tr/bulgaristan-daki-osmanli-camileri-buyuksehir-ile-hayat-buldu/haber/13606; "Turkish Government to Help Restore Ottoman Era Mosque in Bulgaria," TRT World, (March 30, 2018), retrieved January 12, 2018, from https://www.trtworld.com/ art-culture/turkish-government-to-help-restore-ottoman-era-mosque-in-bulgaria-16363.

26. "Muslim Denomination," Grand Mufti's Office-Republic of Bulgaria, retrieved June 3, 2018, from http:// www.grandmufti.bg/bg/home/news-room/novini/30-imami-ot-turtziya-shte-prekarat-mesetz-ramazan-s-myusyulmanite-v-balgariya.html. 
27. "What I Saw at the Islamic School in Momchilgrad [Какво видях в ислямското училище в Момчилград)," Deutsche Welle, (December 19, 2017), retrieved January 12, 2019, from https://www. $\mathrm{dw} . c o m / \mathrm{bg} /$ какво-видях-в-ислямското-училище-в-момчилград/а-41855305.

28. Esra Bulut, "Friends, Balkans, Statesmen Lend Us Your Ears: The Trans-State and State in Links Between Turkey and Balkans," in Denisa Kostovicova and Vesna Bojicic-Dzelilovic (eds.), Transnationalism in the Balkans, (New York: Routledge, 2008), p. 106.

29. "Uluslararası İmam Hatip Lisesi Diyanet Bursları," Türkiye Diyanet Vakfı, retrieved May 16, 2018, from http://burs.tdv.org/medya/dosyalar/kilavuz_tr_lise.pdf.

30. “Bulgaristan Başbakanı Borisov: Diyanet'in Ülkemize Din Adamları Göndermesi Sorun Teşkil Etmiyor," Anadolu Ajansı, (January 25, 2016), retrieved April 29, 2019, from https://www.aa.com.tr/tr/dunya/ bulgaristan-basbakani-borisov-diyanetin-ulkemize-din-adamlari-gondermesi-sorun-teskil-etmiyor/510412.

31. Mehmet Uğur Ekinci, "Türkiye-Balkanlar İlişkileri," SETA Analiz, No: 204, (May 2017), p. 12.

32. "Bulgaristan Diyanet Görevlisini Sınır Dışı Etti," Dünya Bülteni, (January 10, 2009), retrieved April 29, 2019, from https://www.dunyabulteni.net/arsiv/bulgaristan-diyanet-gorevlisini-sinir-disi-etti-h63093. html.

33. "Bulgaristan ile Ataşe Krizi," Hürriyet, (February 22, 2016), retrieved April 29, 2019, from http://www. hurriyet.com.tr/dunya/bulgaristan-ile-atase-krizi-40058725.

34. Mariya Ceresheva, "In Pictures: Historic Bulgarian Church Reopens in İstanbul," Balkan Insight, (January 8, 2018), retrieved April 29, 2019, from https://balkaninsight.com/2018/01/08/landmarkbulgarian-orthodox-church-reopens-in-istanbul-01-05-2018/.

35. "Turkey to Restore Ottoman-era Mosque in Bulgaria," Anadolu Ajansı, (March 8, 2018), retrieved April 29, 2019, from https://www.aa.com.tr/en/europe/turkey-to-restore-ottoman-era-mosque-in-bulgaria-/1083333.

36. Neil Patrick, Saudi Arabian Foreign Policy: Conflict and Cooperation, (New York: I.B.Taurus, 2016), pp. 30-33.

37. "The Foreign Policy of the Kingdom of Saudi Arabia," Kingdom of Saudi Arabia, Ministry of Foreign Affairs, retrieved April 11, 2019, from https://www.mofa.gov.sa/sites/mofaen/KingdomForeignPolicy/ Pages/ ForeignPolicy24605.aspx.

38. Patrick, Saudi Arabian Foreign Policy, pp. 20-25.

39. "Saudi Prince Denies Kushner Is 'in His Pocket,"' The Washington Post, (March 22, 2018), retrieved April 12, 2019, from https://www.washingtonpost.com/world/national-security/saudi-prince-denieskushner-is-in-his-pocket/2018/03/22/701a9c9e-2e22-11e8-8688e053ba58f1e4_story.html?noredirect=on\&utm_term=.e8a4 f506b156.

40. "Cold War-era Wahhabism Used as Tool against Soviets on US Demand, Saudi Crown Prince Salman Confesses," Daily Sabah, (March 28, 2018), retrieved April 12, 2019, from https://www.dailysabah.com/ mideast/2018/03/28/cold-war-era-wahhabism-used-as-tool-against-soviets-on-us-demand-saudicrown-prince-salman-confesses.

41. "Saudi Arabia Is Leading the Fight for True Islam, Says Shoura Council Speaker," Arab News, (November 23, 2017), retrieved May 12, 2018, from http://www.arabnews.com/node/1197841/saudi-arabia.

42. Laurent Bonnefoy, "Saudi Arabia and the Export of Religious Ideologies," NOREF, (September 2013), retrieved May 25, 2018, from https://www.files.ethz.ch/isn/169317/5\%209\%202013.pdf.

43. Rositsa Dzhekova, et al., "Radicalization in Bulgaria: Threats and Trends," Center for the Study of Democracy, (2015), retrieved from https://www.rcc.int/p-cve/download/docs/Radicalisation-in-Bulgaria Threats-and-Trends-Report.pdf/d053eaef6c88c7a0e7edf527ff875988.pdf, p. 35.

44. "Radical Islam not a Religion, but a Political Ideology [Радикалният ислям не е религия, а политическа идеология),, DAIK, (October 13, 2010), retrieved June 26, 2018, from https://dariknews. bg/novini/afera/radikalniqt-islqm-ne-e-religiq-a-politicheska-ideologiq-601624. 
45. "The Hodja of Sirtnitsa - the Leader of Al-Wakf Al-Islami in Bulgaria [Ходжата на Сърница ръководител на "Ал Уакф Ал Ислями" у нас )," Legal World, (October 7, 2010), retrieved May 2, 2018, from http://legalworld.bg/21381.hodjata-na-syrnica-\%E2\%80\%93-rykovoditel-na-al-uakf-al-isliami-unas.html\&orderby $=1$.

46. Nikolov Yoyo, "The Money Comes from the Emessaries [Първи идват емисарите)," Карital, (August 14, 2004), retrieved June 7, 2018, from https://www.capital.bg/politika_i_ikonomika/ bulgaria/2004/08/14/227488_purvi_idvat_emisarite/.

47. "Taiba Welfare Foundation," Taiba Foundation, retrieved May 22, 2018, from http://www.taibafoundation.org/.

48. Diyan Nikolov, "The Uncle of Ben Laden Has Oftenly Visited Bulgaria," Segabg, (September 25, 2001), retrieved June 7, 2018, from http://old.segabg.com/article.php?issueid=1655\&sectionid=2\&id= 00005.

49. "Wikileaks: Bulgaria's Muslims - Target of Islamic Fundamentalism [Българските мюсюлмани - мишена на ислямския фундаментализъм)," Bivol, retrieved May 12, 2018, from https://bivol.bg/ wlislambg.html.

50. "WikiLeaks: Islam and Islamic Extremism in Bulgaria," Sofia News Agency, (July 14, 2011), retrieved May 22, 2018, from http://www.novinite.com/articles/130230/WikiLeaks\%3A+lslam+and+lslamic+ Extremism+in+Bulgaria.

51. "Bulgaria's Muslims not Deeply Religious: Study," Hürriyet Daily News, (December 9, 2011), retrieved May 16, 2017, from http://www.hurriyetdailynews.com/bulgarias-muslims-not-deeply-religious-study8817.

52. Petya Nitzova, "Islam in Bulgaria: A Historical Reappraisal," Religion, State and Society, Vol. 22, No. 1 (1994).

53. Şaban Çalış, et al., Balkanlar'da Siyaset, (Eskişehir: Anadolu Üniversitesi Yayınları, 2015), p. 177.

54. "There Is Something More Dangerous in Bulgaria than Terrorist Act [В България се случва нещо поопасно и от терористичен акт)," The Bulgarian Times, (December 29, 2016), retrieved July 5, 2018, from https://bultimes.com/v-balgariya-se-sluchva-neshto-po-opasno-i-ot-teroristichen-akt/.

55. Merdjanova, Rediscovering the Umma, p. 6. 


\section{SETA}

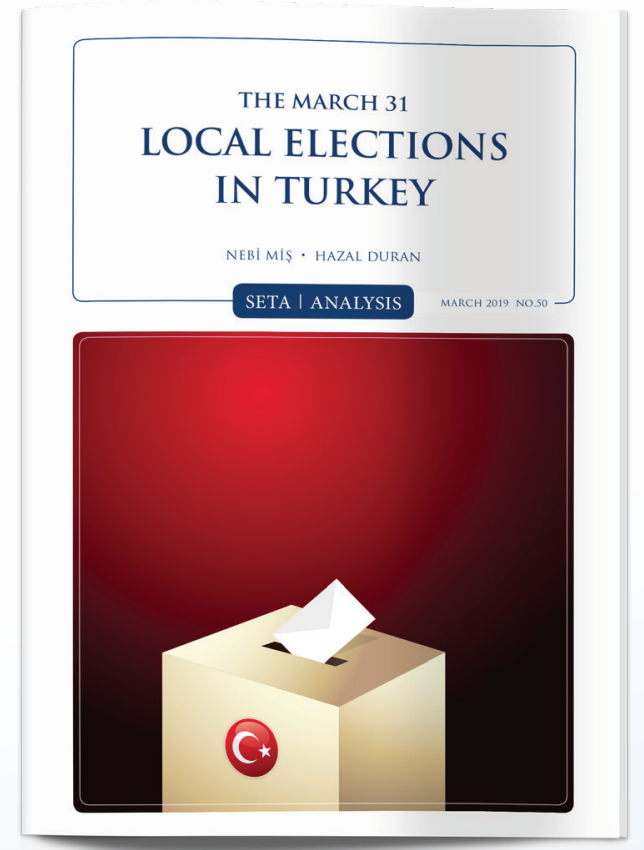

\section{The March 31 Local Elections in Turkey \\ Nebi Miş, Hazal Duran}

This analysis explains the March 2019 local election's significance to Turkish politics and concentrates on the ways in which the visions of various political parties for local government have changed over the years. Accordingly, the analysis primarily discusses the upcoming election's key dynamics. It proceeds to analyze the March 2019 election's significance for each major political party's internal agenda and future projections. Moreover, this analysis offers a detailed account of how each political party's vision for local government has changed over the years and how their respective visions have been tailored for the 2019 local election campaign. Finally, it identifies a number of issues that will possibly set the post-election political agenda in Turkey.

\section{Interfactional Dynamics and the Future of Idlib}

Murat Yeşiltaş, Ömer Özkızılcık

This paper aims to give a brief overview of the recent battle and the dynamics inside Idlib which led to the fighting between the Nureddin Zengi Movement and HTS. Furthermore, the dynamics which enabled HTS to win the battle will be analyzed. Based on the implications for the interfactional dynamics in Idlib, the Sochi agreement between Turkey and Russia has to be adjusted given that certain of its terms couldn't be implemented on the ground. The paper also offers an array of possible scenarios of how Turkey and Russia might adjust the Sochi agreement in order to counter the violent extremist group in Idlib and prevent a humanitarian crisis.

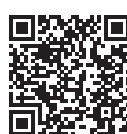

MURAT YEȘILTAȘ. OMER ÖZKIZILCIK SETA I ANALYSIS

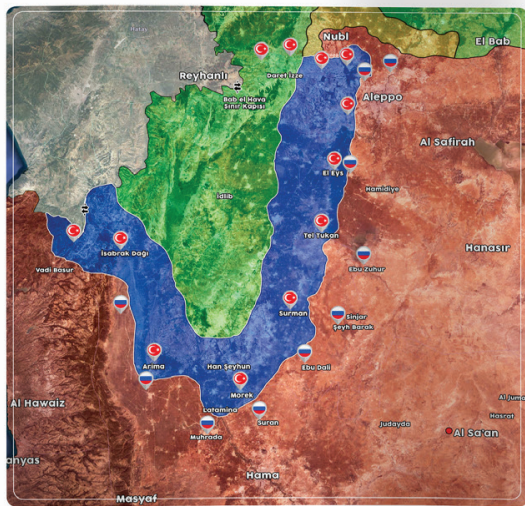




\section{INSIGHT}

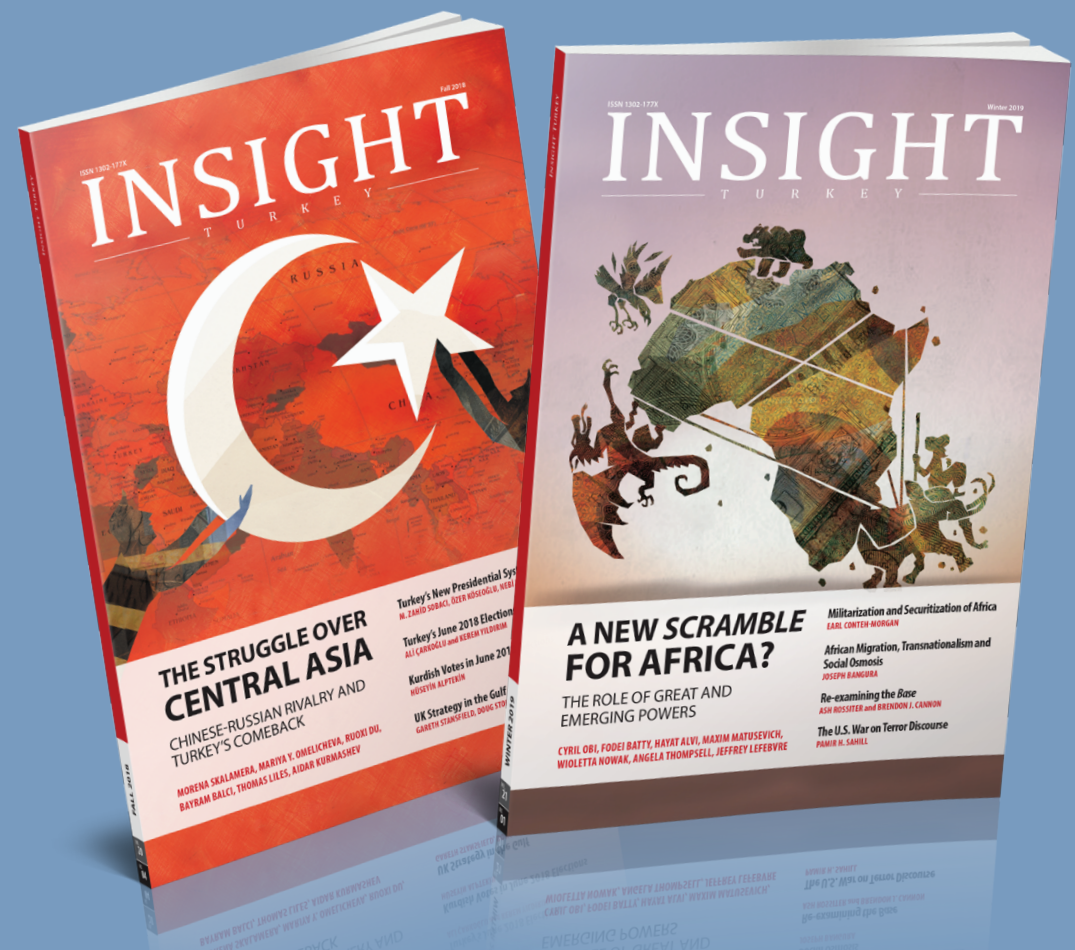

\section{Challenging ideas} on Turkish politics and international affairs

\section{An insightful reference for $\mathbf{2 1}$ years}

